\title{
PELATIHAN ROCK \& WATER TERRHADAP SELF CONTROL REMAJA
}

\author{
Dwi Ratno Priyambodo, Esy Suraeni Yuniwati \\ Fakultas Psikologi Universitas Wisnuwardhana Malang \\ ratnoprijambodo@gmail.com, esysuraeniyuniwati@gmail.com
}

\begin{abstract}
Abstrak: Penelitian ini dilakukan untuk mengetahui pengaruh Pelatihan Rock \& Water terhadap self control remaja. Dengan menggunakan Metode quasi eksperimen peneliti membandingkan kemampuan self control sebelum dilakukan pelatihan dan sesudah dilakukan pelatihan. Hipotesis yang diajukan terdapat hubungan signifikan kemampuan self control sebelum dan sesudah dilakukan pelatihan. Setelah dilakukan perhitungan data terbukti hipotesis yang diajukan ditolak. Hasil pelatihan menunjukkan adanya peningkatan kemampuan self control remaja, namun perbedaan tersebut tidak cukup signifikan.
\end{abstract}

Kata Kunci: Remaja; Pelatihan Rock\&Water; Self Control

Abstrac: his study was conducted to determine the effect of Rock \& Water Training on adolescent self control. By using the quasi-experimental method researchers compared the ability of self control before training and after training. The hypothesis proposed there is a significant relationship between the ability of self control before and after training. After calculating the data it is proven that the proposed hypothesis is rejected. The training results showed an increase in adolescent self-control abilities, but the difference was not significant enough.

Keyword: adolescence, Rock\&Water training; self control

\section{PENDAHULUAN}

Persoalan remaja memang menarik untuk diangkat sebagai topik penelitian. Dalam teori dan kajian psikologi perkembangan, fase Remaja digambarkan sebagai fase yang penuh "gejolak", dalam bukunya Santrock (2007) menyebutkan sebagai fase "storm and stress". Dalam fase ini secara umum seorang remaja digambarkan sebagai sosok yang bermasalah, egosentris dan penuh pemberontakan terhadap otoritas baik dengan orangtua maupun dengan guru di sekolah.

Data UNICEF tahun 2016 menunjukkan bahwa kekerasan pada sesama remaja di Indonesia diperkirakan mencapai 50 persen. Sedangkan dilansir dari data Kementerian Kesehatan RI 2017, terdapat 3,8 persen pelajar dan mahasiswa yang menyatakan pernah menyalahgunakan narkotika dan obat berbahaya (FKKMK.UGM, 2018).

Lahirnya beragam tindak kekerasan dan pelanggaran hukum dikalangan remaja tidak dapat dikaitkan langsung dengan persoalan fase perubahan secara fisik dan psikis semata. Namun kondisi social tempat remaja bertumbuh dan berkembang juga mempunyai andil yang cukup besar.

Menurut Conny Semiawan, peran orangtua perlu menciptakan lingkungan dan keluarga yang serasi, dan seimbang terutama bagi anak berbakat dengan menegambangkan sikap demokatis agar anak menjadi lebih percaya diri dan mandiri. Santrock (2007) dalam bukunya menjelaskan adanya pengaruh dyadic antara remaja dengan ibu maupun dengan ayahnya. Diketemukan adanya relasi positif hubungan dyadic antara remaja dan ayah, yaitu kemampuan seorang ayah dalam mengendalikan perilaku negative 
anak. Lebih lanjut Santrock (2007) mengemukakan peran orangtua di masa dini akan terbawa seumur hidup dan mempengaruhi seorang remaja. Artinya relasi orangtua dan anak berfungsi sebagai model atau cetakan yang akan dibawa seumur hidupnya.

Dalam proses perkembangannya, seorang remaja dituntut untuk memiliki ketrampilan social yang berfungsi untuk membangun persahabatan dengan sebayanya. Hal ini memberikan dampak positif bagi remaja. Seperti ditunjukkan oleh De Rossiser \& Marcus (Santrock, 2007) bahwa remaja yang memiliki ketrampilan social akan membantunya meningkatkan penerimaan social dan harga diri. Sebaliknya bagi remaja yang gagal akan memperoleh reputasi negative dari sebayanya.Seperti dikemukakan oleh Gottman\&Parker (Santrock, 2007), persahabatan bagi seorang remaja akan membantunya memperoleh dukungan secara fisik serta dukungan bagi ego sebagai umpan balik yang diberikan orang lain bahwa dirinya sebagai sosok yang kompeten, menarik dan berharga.

Dari sisi tingkat social-ekonomi orangtua juga membawa dampak bagi perkembangan remaja, terutama pada tingkatan yang lebih rendah. Seperti dikemukakan Magnusson\&Duncan (dalam Santrock, 2007), permasalah yang sering muncul adalah munculnya gangguan mental dan penyesuaian social. Pada keluarga dengan tingkat social ekonomi yang lebih rendah, orangtua dituntut untuk bekerja di luar rumah sehingga intensitas pertemuan dengan anaknya relative sedikit. Richards (dalam Santrock, 2007) menemukan fakta bahwa anak-anak lebih banyak mengalami hukuman fisik di rumah sendiri sehingga memunculnya pengalaman negative pada diri anak. Hal ini dikuatkan oleh penelitian Balitbang Depsos (http://www.depsos. go.id /Balatbang / Puslitbang.2004.pdf,) menemukan fakta bahwa intensitas pertemuan dengan keluarga, 70\% remaja merasa bahwa intensitas pertemuan keluarga masih belum maksimal, yang meliputi kategori jarang sebanyak 33,33\% dan kategori sangat jarang 36,67\%. Besarnya angka ini mencerminkan bahwa menurut remaja sebagian besar keluarga masih kurang memperhatikan aspek kebutuhan sosial keluarga sesuai dengan tuntutan kebutuhan. Sebuah studi longitudinal yang dilakukan oleh Laird (Santrock, 2007) menunjukan bahwa semakin sedikit aktivitias dan keberadaan remaja yang diketahui oleh orangtua, maka semakin besar kecenderungan remaja untuk terjerumus dalam peilaku kenakalan.

Minimnya ketrampilan sosial yang dimiliki seorang remaja serta perhatian dan dukungan sosial yang diterima menyebabkan munculnya beberapa permasalahan, baik dengan keluarga/orang tua dan dengan teman sebayanya. Berbagai macam permasalahan remaja seperti dikemukakan oleh Santock (2007) antara lain penggunaana obat terlarang, merokok, alkohol dan berbagai bentuk pelanggaran lainnya. Jadi kenakalan remaja dibatasi dengan pengertian berbagai perilaku yang tidak dapat diterima secar sosial seperti berbuat onar di sekolah, status pelanggaran seperti melarikan diri dari rumah, hingga tindakan kriminal seperti pencurian (Santrock, 2007).

\section{Self Control}

Kontrol diri berkaitan dengan bagaimana individu mengendalikan emosi serta dorongan-dorongan dari dalam dirinya (Hurlock, 1990). Menurut konsep ilmiah pengendalian emosi berarti mengarahkan energi emosi ke saluran ekspresi yang bermanfaat dan dapat di terima secara sosial. Memang konsep ilmiah menitik beratkan pada pengendalian, tetapi tidak sama artinya dengan penekanan. Mengontrol emosi berarti mendekati suatu situasi dengan menggunakan sikap yang rasional untuk merespon situasi tersebut 
dan mencegah munculnya reaksi yang berlebihan.

Menentukan apakah kontrol emosi dapat diterima secara sosial atau kontrol emosi tidak dapat diterima, terdapat dua kriteria. Bila reaksi masyarakat terhadap pengendalian emosi adalah positif. Namun reaksi positif saja tidaklah cukup karenanya perlu diperhatikan kriteria lain, yaitu efek yang muncul setelah mengontrol emosi terhadap kondisi fisik dan praktis, kontrol emosi seharusnya tidak membahayakan fisik, dan psikis individu. Artinya dengan mengontrol emosi kondisi fisik dan psikis individu harus membaik (Hurlock, 1990).

Hurlock (1990) menyebutkan tiga kriteria kontrol emosi sebagai berikut:

a) Dapat melakukan kontrol diri yang bisa di terima secara sosial.

b) Dapat memahami seberapa banyak kontrol yang dibutuhkan untuk memuaskan kebutuhannya dan sesuai dengan harapan masyarakat.

c) Dapat menilai situasi secara kritis sebelum meresponnya dan memutuskan cara beraksi terhadap situasi tersebut.

Berdasarkan penjelasan di atas, maka kontrol diri dapat diartikan sebagai suatu aktivitas pengendalian tingkah laku, yang meliputi perhatian, hambatan respon dan cara berkespresi yang unik dari individu untuk menahan godaan yang muncul pada saat itu. untuk mengatasi suatu respon yang diterima dari lingkungan dengan bentuk perilaku nyata yang diterima oleh norma/aturan.

Beberapa faktor yang bisa menyebabkan munculnya kenakalan pada remaja selain karena konflik dengan otoritas juga relasi dengan kawan-kawan sebayanya. Penelitian Henry, Tolan \& Gorman-Smith (Santrock, 2007) menyebutkan bahwa berelasi dengan kawan-kawan sebaya yang nakal dapat meningkatkan resiko seorang remaja menjadi nakal. Beberapa penelitian terbaru menunjukkan bahwa kenakalan remaja bukan hanya terjadi di keluarga dengan tingkat sosial ekonomi rendah namun juga pada keluarga dengan tingkat sosial ekonomi menengah bahkan yang tinggi. Secara lebih spesifik Farington (Santrock, 2007) mencatat sifat dasar komunitas seperti komunitas dengan angka kejahatan tinggi dapat menyebabkan remaja mengamati banyak model yang terlibat dalam aktivitas kriminal dan mungkin mereka dihargai karena perilaku tersebut.

Barlow dkk (dalam Ezinga, 2008) mengidentifikasi 6 dimensi dari selfcontrol berdasarkan mekanisme pengaturan yang dikemukakan dalam teori Gottfredson dan Hirschi. Dimensi tersebut adalah :

1. Impulsivity, individu yang berorientasi pada "di sini dan sekarang" (here and now)

2. Risk seeking, individu yang memiliki kecenderungan untuk mencari tindakan yang beresiko, mendebarkan dan "menggairahkan"

3. Temper, individu yang memiliki toleransi yang rendah terhadap frustasi, dan kemampuan yang terbatas untuk mengatasi konflik dan lebih banyak merespon konflik dengan menggunakan verbal daripada tindakan fisik.

4. Preference of simple tasks, kecenderungan individu untuk menghindari tugas-tugas yang cukup kompleks, dan berkurangnya antusiasme atau kegigihan untuk menyelesaikan suatu tugas yang sudah dimulai.

5. Physical (risky) activities, individu memiliki kecenderungan untuk melakukan aktivitas fisik yang beresiko daripada kegiatan kognitif dan mental.

6. Self-centered (egois), mementingkan diri sendiri atau ketidakpekaan terhadap orang lain.

Sebagaimana faktor psikologis lainnya kontrol diri dipengaruhi oleh beberapa faktor. Secara garis besarnya faktor-faktor yang memepengaruhi kontrol diri ini terdiri dari faktor internal (dari diri 
individu), dan faktor eksternal (lingkungan individu).

1. Faktor internal

Faktor internal yang ikut andil terhadap kontrol diri menurut Fox and Calkins (2003) adalah proses kognitif yang meliputi perhatian, respon yang terhambat dan fungsi eksekutif (khusus) serta usia (Loevinger's dalam Ezinga, 2008) .

2. Faktor eksternal.

Faktor eksternal ini diantaranya adalah lingkungan keluarga (Hurlock, 1990). Lingkungan keluarga terutama orangtua menentukan bagaimana kemampuan mengontrol diri seseorang. Sedangkan menurut Fox and Calkins (2003) faktor eksternal meliputi proses sosialisasi/interaksi yang dialami anak dengan lingkungannya dimana Ia mempelajari berbagai strategi selfcontrol dan ekspresi emosi yang diterima oleh lingkungan.

Dalam pendekatan psikopatologi perkembangan seperti dikemukakan Santrock (2007), masalah-masalah remaja dapat dikategorikan dalam internalisasi masalah yang menyebabkan invidu akan mengarahkan problem yang sedang dihadapi ke dalam dirinya sehingga memunculkan kecemasan dan depresi, serta eksternalisasi problem yang mengarahkan persoalan yang dialami remaja ke luar dari dirinya dalam bentuk kenakalan. Dari sisi psikologis, munculnya kenakalan remaja lebih banyak disebabkan oleh gangguan berpikir, gejolak emosional, proses belajar yang keliru serta relasi yang bermasalah. Di awal pembahasan bagian ini, penulis menjelaskan kondisi remaja yang tidak stabil secara emosional mnejadi ciri utama di fase remaja. Dengan kondisi demikian, mereka akan lebih mudah mengambil suatu keputusan atau tindakan untuk mengurangi rasa cemas tanpa proses pertimbangan yang matang. Seperti dikemukakan oleh Evi Aviyah (2014) menemukan adanya hubungan antara religiusitas, kontrol diri dan kenakalan remaja. Hasil analisis data menggunakan Anareg mendapatkan hasil $\mathrm{F}$ Regresi = 17,954 dengan $p=0,00(p<0,01)$. Variabel religiusitas dan kontrol diri secara simultan dan sangat signifikan berkorelasi dengan kenakalan remaja. Demikian pula dengan penelitian Fitiraningrum M. (2015) memperoleh hasil variabel kontrol diri memberikan kontribusi pada perilaku kenakalan remaja sebesar 21,5\% sedangkan $78,5 \%$ dipengaruhi oleh faktor lain.

Berbagai upaya dan program dibuat oleh beberapa negara utamanya negara maju seperti di Amerika Serikat untuk menekan angka kenakalan di kalangan remaja, baik program yang bersifat kuratif maupun preventif.

\section{Pelatihan Rock \& Water}

Sebuah studi yang dilakukan oleh Morris dkk (2003) menggambarkan suatu program yang menggunakan kegiatan olahraga secara fisik sebagai upaya untuk mengurangi perilaku antisosial di beberapa bagian di Australia. Manfaat berolahraga dapat dilihat dari dua aspek. Salah satunya manfaat olah raga terhadap otak yang diungkapkan oleh Daniel Landers, profesor pendidikan olahraga dari Arizona State University tahun 2008. (http://www. Bloggaul.com/purnomo_w/readblog/9133 5/5-manfaat-olahraga-bagi-otak, diakses tgl. 20 Mei 2011.), antara lain; meningkatkan kemampuan otak. Latihan fisik yang rutin dapat meningkatkan konsentrasi, kreativitas, dan kesehatan mental. Karena olahraga bisa meningkatkan jumlah oksigen dalam darah dan mempercepat aliran darah menuju otak. Para ahli percaya bahwa halhal ini dapat mendorong reaksi fisik dan mental yang lebih baik. Membantu menunda proses penuaan. Riset membuktikan bahwa latihan sederhana seperti jalan kaki secara teratur dapat membantu mengurangi penurunan mental 
pada wanita di atas 65 tahun. Mengurangi stres, olahraga dapat mengurangi kegelisahan. Menaikkan daya tahan tubuh. Jika senang melakukan olahraga meski tak terlalu lama namun sering atau lama namun dengan santai melakukannya, maka aktivitas itu bisa meningkatkan hormonhormon baik dalam otak seperti adrenalin, serotonin, dopamin, dan endorfin. Hormon ini berperan dalam meningkatkan daya tahan tubuh. Studi yang dilakukan di Inggris (2007) memperlihatkan bahwa $83 \%$ orang yang memiliki gangguan mental mengandalkan olahraga untuk meningkatkan mood dan mengurangi kegelisahan. Serta memperbaiki kepercayaan diri, umumnya semakin mahir seseorang dalam suatu jenis aktivitas, maka kepercayaan diri pun akan meningkat. Bahkan suatu riset membuktikan bahwa remaja yang aktif berolahraga merasa lebih percaya diri dibandingkan dengan temantemannya yang tidak melakukan kegiatan serupa.

Sejalan dengan temuan Morris dan Landers, serta Ykema (2002) yang mendesign program Rock and Water dengan. menggunakan dasar pembelajaran psycho-physical, artinya titik pijak awal adalah latihan fisik dasar untuk mengajar dan belajar kemampuan mental dan sosial. Program ini dirancang untuk anak usia 10 tahun - 18 tahun dengan menekankan pada aspek fisik dan didukung dengan diskusi kecil dengan pemberian ruang untuk refleksi diri dan pengerjaan tugas singkat. Ykema (2002) menemukan fakta bahwa anak laki-laki cenderung memiliki prestasi yang kurang di sekolah, anak laki-laki sering menjadi pelaku kejahatan, anak lakilaki juga mengalami banyak kesulitan untuk membahasakan isi pikiran, perasaaan dan emosi mereka dibandingkan dengan anak perempuan.

Program ini menggunakan pengajaran psycho-physical, artinya titik pijak awal pada latihan fisik dasar untuk mengajar dan belajar kemampuan mental dan sosial. Itu sebabnya, program ini sangat menekankan fisik dan didukung dengan diskusi kelompok kecil dengan pemberian ruang untuk refleksi diri dan pengerjaan tugastugas singkat. Titik pijak awal ini dipilih sebab anak laki-laki sangat terkenal dengan kekuatan fisiknya, namun anak laki-laki mempunyai kesulitan untuk membahasakan isi pikiran, perasaan dan emosi mereka dibandingkan dengan anak perempuan. Pendekatan psycho-physical dimaksud untuk 'sekali tepuk, dua burung tertangkap sekaligus': anak laki-laki diajarkan untuk menguasai dan memusatkan energi mereka, dan di saat yang sama berkomunikasi dengan bentuk gerakan fisik untuk menolong mereka belajar kemampuan berkomunikasi.

Dasar "bangunan" Rock and Water adalah penguasaan diri, refleksi diri, dan kepercayaan diri. Membangun mental anak di atas fondasi tersebut memungkinkan untuk memberi perhatian pada tema-tema keamanan (safety), ketegasan (assertiveness), komunikasi dan menemukan jalan mereka sendiri (inner compass) yang akan menghubungkan mereka dengan orang lain dalam solidaritas, dan memberi mereka arah (spiritualy). "Rock" menggambarkan secara simbolik pendekatan yang bersifat kaku (rigid) dan tidak mengenal kompromi sedangkan "Water" menggambarkan kelenturan (fleksibility), komunikasi dan kerjasama (cooperation). Sehingga pelatihan ini bertujuan melatih anak agar memiliki kesadaran bahwa mereka memiliki nilai berbeda dari yang lain dan nilai diri itu merupakan manifestasi diri mereka sebagai kekuatan yang bekerja untuk menghasilkan pemenuhan diri (meaningfull).

Tema-tema yang disebutkan di atas saling terkait dalam program melalui 4 (empat) urutan yang mudah:

1. Grounding (berpijak), centring (berpusat) dan focusing (fokus): belajar bagaimana berdiri kokoh dan relaks, 
mengkonsentrasikan nafas di perut dan perhatian yang fokus (pertama-tama secara eksternal, kemudian diubah menjadi tujuan internal).

2. the golden triangle of body-awareness - emotional awareness - self awareness. Emosi diekspresikan tubuh melalui otototot yang mengencang. Oleh karena itu, meningkatkan kesadaran tubuh dapat membimbing pada pemahaman yang mendalam dan pengalaman terhadap pola reaksi diri sendiri, kemudian dapat dituntun untuk perubahan yang lebih mendalam dan perkembangan selanjutnya, yaitu kesadaran emosi dan kesadaran diri.

3. Communication (komunikasi): Perkembangan bentuk komunikasi fisik adalah dasar untuk perkembangan lain, lebih berorientasi verbal.

4. The Rock and Water concept : Sikap batu karang yang keras dan tak tergoyahkan melawan sikap air yang lebih luwes. Konsep ini dapat dikembangkan dan diaplikasikan pada macam-macam tingkatan: tingkat fisik, mental dan sosial. Pada tingkat fisik hal itu berarti sebuah serangan dapat ditangkis dengan otot yang benar-benar tegang (Rock), tetapi juga bisa bahkan seringkali lebih efektif dengan bergerak dengan menggunakan energi si penyerang (water). Pada tingkat sosial, misalnya dalam sebuah percakapan, juga sangat mungkin untuk memilih antara sikap batu karang dan sikap air, dan pilihan yang sama berlaku untuk memelihara hubungan dengan orang lain.

Metode kegiatan yang akan digunakan dalam Pelatihan Rock and Water adalah ;

1. Salam Rock and Water dengan aktivitas fisik,

2. Diskusi kelompok singkat untuk menjelaskan isi dan tujuan pelatihan setiap pelajaran

3. Latihan
4. Setelah tiap latihan dan sesekali di tengah-tengah latihan, merangsang para siswa untuk tetap focus pada pusat (center) mereka serta untuk merangsang refleksi diri dan kesadaran diri.

\section{Self Control dan Program Rock \& Water}

Self-control adalah kapasitas yang berkembang selama tahun-tahun pertama kehidupan individu dan memberikan efek pada suatu gambaran terbentuknya perilaku anak. Pengertian tentang pengendalian diri dibahas dalam literatur psikologis dalam kaitannya dengan pengembangan keterampilan motorik, perhatian, kognisi, dan berkaitan dengan emosi. Kemampuan untuk mengendalikan ekspresi emosi, terutama emosi negatif, berkembang selama tahun pertama kehidupan dan penting untuk terbentuknya perilaku sosial yang tepat dan adaptif. Selain itu, kurangnya pengembangan yang cukup terhadap kontrol emosi mungkin dapat memicu perkembangan psikopatologi (Fox and Calkins, 2003).

Self-control mengacu pada upaya untuk mengesampingkan atau mengubah kecenderungan salah satu respon yang dominant (Bandura, dalam Schemeichel and Zell, 2007). Beberapa penelitian menunjukkan adanya perbedaan kemampuan individu untuk mengntrol diri. Penelitian Brandon dkk (dalam Schemeichel and Zell, 2007) menemukan indikasi bahwa kemampuan seseorang untuk mengatasi suatu respon akan stabil dan menjadi ciri khusus individu yang bersifat terus menerus dari waktu ke waktu dan mungkin perilaku ini akan terus dipergunakan individu untuk menghadapi jenis perilaku menantang lainnya.

Teori krimonologi yang sering dipergunakan untuk menjelaskan keterlibatan individu dalam tindak kejahatan adalah teori self-control dari Gottfredson dan Hirschi's (dalam Conner, 2008). Teori ini menitikberatkan perhatian pada tingkat pengendalian diri (self- 
control) sebagai variabel utama dan independent, sebagai penentu munculnya perilaku jahat dan perilaku deliquensi. Beberapa studi empiris membuktikan adanya hubungan antara tingkat pengendalian diri (self-control) yang rendah dengan prevalensi munculnya perilaku jahat atau nakal.(Blokland dkk dalam Ezinga, 2008).

Penelitian yang dilakukan oleh Ezinga dkk (2007) ingin menunjukkan adanya relevansi perspektif perkembangan psikososial berdasar teori Loevinger untuk menjelaskan adanya perilaku menyimpang dan perilaku kenakalan remaja. Penelitian dilakukan Gottfredson dan Hirschi's kepada sekitar 800 siswa yang memiliki usia $12-13$ tahun. Hasil penelitian ini menunjukkan bahwa rendahnya selfcontrol berhubungan dengan munculnya perilaku menyimpang dan kenakalan pada remaja. Tingkat perkembangan responden juga berhubungan dengan tingkat selfcontrol. Analisa kovarian yang dilakukan dalam penelitian ini mendapatkan adanya efek yang terpisah, bahwa self-protective berada pada level moderat sedangkan jumlah keseluruhan perilaku menyimpang berada di bawah rendahnya self-control.

Sedangkan penelitian Fox and Calkins (2003) menunjukkan adanya faktor intrinsik dan ekstrinsik yang mempengaruhi perkembangan self-control of emotion. Faktor intrinsik meliputi temperament selama masa bayi, dan proses kognitif yang meliputi kemampuan perhatian dan pengendalian terhadap kontrol. Sedangkan faktor ekstrinsik meliputi lingkungan pengasuhan, hubungan dengan saudara dan teman sebaya dan harapan kultural tentang cara mengekspresikan emosi.

Berdasarkan semua penelitian yang sudah pernah dilakukan sebelumnya, peneliti mengamati bahwa variabel penelitian Rock and Water belum secara langsung dikaitkan dengan variabel self- control sehingga dapat dikatakan penelitian ini masih memiliki nilai originalitas.

Berpijak pada fakta di atas, penelitian ini ingin meneliti lebih jauh pengaruh pelatihan program Rock and Water terhadap Peningkataan Self- Control pada Remaja

\section{METODE}

Penelitian ini menggunakan rancangan quasi eksperimen untuk mengetahui perbedaan self control siswa sebelum dan sesudah dilakukan pelatihan / treatment.

Desain yang digunakan dalam penelitian ini adalah Randomized Control Group Pretest-Posttest Design, yaitu suatu bentuk eksperimen yang menggunakan kelompok eksperimen yang dikenai variable perlakuan $\mathrm{X}$ dan kelompok kontrol yang tidak dikenai variable perlakuan.

Langkah-langkah Eksperimen meliputi

1. Melakukan Pre-tes pada kelompok eksperimen dan kelompok kontrol. Menentukan siswa yang masuk dalam kelompok kontrol dan kelompok eksperimen secara acak atau random.

2. Memberikan pelatihan Rock and Water pada kelompok eksperimen sebanyak 3 kali pertemuan.

3. Melakukan Post-test pada kelompok eksperimen dan kelompok kontrol pada akhir kegiatan pelatihan.

Responden dalam penelitian ini adalah siswa kelas XI SMP Pamerdi Malang yang berjumlah 16 siswa.

Tabel 1

Desain Randomized Control - Group PretestPosttest Design

Pretest Treatment Posttest

\begin{tabular}{llll}
$\begin{array}{c}\text { Experiment } \\
\text { Group }\end{array}$ & T1 & $X$ & T2 \\
$\begin{array}{c}\text { Control } \\
\text { Group }\end{array}$ & T1 & & T2 \\
\hline
\end{tabular}


Keterangan

$$
\begin{array}{ll}
\mathrm{T} 1= & \text { Perlakuan awal (pretest) } \\
\mathrm{X} & = \\
& \text { Perlakuan berupa pelatihan Rock } \\
& \text { and Water } \\
\mathrm{T} 2 & \text { Tes akhir (Posttest) }
\end{array}
$$

Penelitian ini dilakukan dengan cara mengukur control diri siswa sebelum dan sesudah dilakukan "treatment" berupa pelatihan Rock \& Water dengan menggunakan skala yang terdiri dari 48 butir pernyataan / ítem.

\section{HASIL}

Untuk menguji adanya perbedaan dan pengaruh antara sebelum dan sesudah pelatihan Rock and Water digunakan uji one way ANOVA, dengan asumsi varians dari populasi tersebut adalah sama, dan populasi yang akan diuji berdistribusi normal.

1. Perbedaan Pre Test Self Control antara Kelompok Kontrol dan Kelompok Eksperimen.

Self Control Kelompok Kontrol dan Kelompok Eksperimen, menunjukkan nilai $F=0,457$ pada $p=0,139(p>0,05)$ sehingga tidak ada perbedaan yang signifikan. Hal ini juga didukung dengan hasil koefisien $t=-1,568$ pada $p$ $=0,139(\mathrm{p}>0,05)$, yang menunjukkan bahwa perbedaan Mean Pre-Test Kelompok Kontrol (yaitu sebesar 78,29) dan Kelompok Eksperimen (yaitu sebesar 83,89) sebesar $-5,603$ tidak cukup signifikan perbedaannya.

Tabel 2. Uji F

\begin{tabular}{llccc}
\hline Variabel & Kelompok & Mean & F & Sig. \\
\hline Self & & & 0,45 & 0,13 \\
Control & Kontrol & 78,29 & 7 & 9 \\
& Eksperimen & 83,89 & & \\
\hline
\end{tabular}

2. Perbedaan Post Test Self Control antara Kelompok Kontrol dan Kelompok Eksperimen.

Self Control Kelompok Kontrol dan Kelompok Eksperimen, menunjukkan nilai $\mathrm{F}=0,059$ pada $\mathrm{P}=0,811(\mathrm{P}>0,05)$ sehingga tidak ada perbedaan yang signifikan. Hal ini didukung dengan hasil koefisien $t=0,269$ pada $p=0,793$ ( $p>0,05)$, yang menunjukkan bahwa perbedaan Mean antara kelompok kontrol (yaitu sebesar 83,57) dan kelompok eksperimen (yaitu sebesar 82,44) sebesar 1,127 tidak cukup signifikan perbedaannya.

Tabel 3. Uji F

\begin{tabular}{llccc}
\hline Variabel & Kelompok & Mean & F & Sig. \\
\hline Self & & & & \\
Control & Kontrol & 83,57 & 0,059 & 0,811 \\
& Eksperimen & 82,44 & & \\
\hline
\end{tabular}

3. Perbedaan Pre Test dan Post Test, Self Control dan Self Esteem pada Kelompok Eksperimen.

Pre Test dan Post Test Self Control pada Kelompok Eksperimen menunjukkan nilai $F=0,098$ pada $p=0,759(p>0,05)$ sehingga tidak ada perbedaan yang signifikan.

Table 4. hasil Uj F

\begin{tabular}{llccc}
\hline Variabel & Kelompok & Mean & F & Sig. \\
\hline Self & & & & \\
Control & Kontrol & 83,89 & 0,098 & 0,759 \\
& Eksperimen & 82,44 & & \\
\hline
\end{tabular}

Hal ini didukung dengan hasil koefisien $t=0,312$ pada $p=0,759(p>$ 0,05 ), yang menunjukkan bahwa perbedaan Mean antara self control sebelum pelatihan (yaitu sebesar 83,89) dan self control setelah pelatihan (yaitu sebesar 82,44) sebesar 1,444 tidak cukup signifikan perbedaannya.

\section{PEMBAHASAN}

Hipotesis penelitian yang berbunyi ada pengaruh pelatihan Rock and Water terhadap peningkatan self control berdasar penelitian ternyata yang tidak terbukti.

Sesuai dengan pendapat Gottfredson and Hirschi (dalam Ezinga, 2008), asumsi utama dari teori General Theory of Crime adalah tingkat self control yang relatif stabil mulai dari akhir masa kanak-kanak sampai usia selanjutnya. Oleh karena itu pelatihan Rock and Water yang 
dilaksanakan dalam penelitian ini tidak menunjukkan peningkatan pada kemampuan self control.

Sejalan dengan teori perkembangan psikososial dari Loevinger, usia $10-13$ tahun berada pada level E 3 (self protective), yang menunjukkan karakteristik kemampuan mengelola diri secara mandiri dan merasa tak terbantahkan. Oleh karena itu aturan yang dibuat oleh pihak lain akan cenderung dilanggar selama individu tersebut tidak merasa dijebak dan mendapatkan hukuman. Dalam hal ini, reaksi remaja seringkali nampak opportunis dan remaja mencari sebagian besar cara untuk berinteraksi dengan orang lain. Remaja akan berusaha mengontrol dorongan impulsnya, tetapi pada waktu yang bersamaan Ia tetap menunjukkan emosi yang negatif.

Sedangkan hasil penelitian Barndon dkk (dalam Schmechel\&Zell, 2007) menunjukkan hasil, bahwa kemampuan untuk mengesampingkan tanggapan yang dominan merupakan kemampuan yang stabil atau yang bertahan dari waktu ke waktu. Sedangkan menurut Rothbart, Derryberry, \& Hershey, (2000) (dalam Fox and Calkins, 2003). Kontrol diri dari emosi muncul pada awal masa bayi dan dipengaruhi oleh reaktivitas bayi terhadap stimulasi lingkungan. Tanggapan awal dari bayi yang ditandai dengan reaksi mereka secara fisiologis dan munculnya bentukbentuk perilaku sebagai tanggapan terhadap rangsang atau stimulus dari lingkungan yang berbeda kualitas dan intensitasnya. Reaktivitas ini hadir pada saat lahir dan mencerminkan karakteristik yang relatif stabil.

Jadi dalam fase ini seorang anak sudah memiliki kemampuan untuk mengontrol dorongan impulsnya atau sudah memiliki kemampuan self control.

\section{KESIMPULAN}

Variabel self control tidak menunjukkan perbedaan antara sebelum dan sesudah dilakukan pelatihan.

\section{SARAN}

a) Bagi Peneliti selanjutnya: Penelitian ini disadari terdapat beberapa kelemahan terutama dari ketersediaan waktu yang sangat singkat sehingga penyampaian materi dan fungsi penerapannya dalam kehidupan sehari-hari siswa perlu lebih dipertajam. Disamping itu, adaptasi pelatihan Rock and Water yang berbasis pada budaya Indonesia perlu untuk dikembangkan.

b) Pemilihan tempat pelatihan juga perlu dipertimbangkan supaya pelaksanaannya dapat berlangsung dengan aman dan nyaman bagi perserta pelatihan.

\section{DAFTAR PUSTAKA}

Azwar, 1999, Penyusunan Skala Psikologi, Jogjakarta : Pustaka Pelajar

Bengoechea dkk., 2010, Exploring Links to Unorganized and Organized Physical Activity During Adolesence, Research Quarterly for Exercise and Sport; 81, 1; Platinum Periodicals pg. 7

Campbell, D.T \& Stanley, J.C. 1973. Experimental and Quasi Experimental Design for Research. Chichago. Rana Mc nally College Publishing Company.

Conner Bradley T., Examining, 2008, SelfControl as a Multidimensional Predictor of Crime and Drug Use in Adolesence with Criminal histories, Journal Of Behavioral Health Service and Research.

Elizabeth Hurlock, 1990, Psikologi Perkembangan (suatu pendekatan sepanjang rentang kehidupan) ed. 5, Penerbit Erlangga-Jakarta. 
Freerk Ykema, 2005, Rock and Water Pelatihan Untuk Membangun Kecakapan Bersosialisasi (terjemahan), Gadaku institue.

Fred N. Kerlinger, 1990, Asas-asas Penelitian Behavioral, Yogyakarta: Gajahmada University Press.

Fox and Calkins, 2003, The Development of Self-Control of Emotion Intrinsic and Extrinsic Influences, Journal Motivation and Emotion. Vol 27, No. 1, University of Maryland.

Hardwick K.,Herbert and Brannigan Augustine, 2008, Self-Control, Child Effects, and informal Social Control: A Direct Test of the Primacy of Sociogenic factors, Canadian Journal of Criminology and Criminal Justice.

John W. Santrock, 2002, Life-Span Development (Perkembangan Masa
Hidup), ed. 5 , Penerbit ErlanggaJakarta.

John W. Santrock, 2007, Remaja edisi 11 jilid 1 , Jakarta: Penerbit Erlangga.

John W. Santrock, 2007, Remaja edisi 11 jilid 2 , Jakarta: Penerbit Erlangga.

M.A.J. Ezingaa, F.M.dkk., 2008, Early adolescence and delinquency: Levels of psychosocial development and selfcontrol as an explanation of misbehaviour and delinquency, Psychology, Crime and Law Vol. 14, No. 4.

Schmeichel Brandon J.. and Zell, Anne, 2007, Trait Self-Control Predict Performance on Behavioral Test of Self-Control, Journal of Personality 75: 4 